\title{
PHYSICAL ACTIVITY OF PHYSIOTHERAPY STUDENTS AT THE MEDICAL UNIVERSITY OF WARSAW
}

\section{AKTYWNOŚĆ FIZYCZNA STUDENTÓW KIERUNKU FIZJOTERAPIA WARSZAWSKIEGO UNIWERSYTETU MEDYCZNEGO}

\section{Dariusz Boguszewski ${ }^{1(\mathrm{~A}, \mathrm{~B}, \mathrm{C}, \mathrm{D}, \mathrm{E}, \mathrm{G})}$, Andrzej Ochal ${ }^{1(\mathrm{~B}, \mathrm{C}, \mathrm{D})}, \mathbf{J a k h u b}$ Adamczyk $^{2(\mathrm{~B}, \mathrm{C})}$, Paweł Jasiński $^{1(\mathrm{~B})}$, Agata Szymańska $^{1(\mathrm{~B})}$, Anna Obszyńska-Litwiniec ${ }^{1(\mathrm{~B})}$, Dariusz Białoszewski ${ }^{1(\mathrm{E})}$}

${ }^{1}$ Department of Rehabilitation, Medical University of Warsaw, Poland

${ }^{2}$ Department of Theory of Sport, University of Physical Education in Warsaw, Poland

Authors' contribution Wkład autorów:

A. Study design/planning zaplanowanie badań B. Data collection/entry zebranie danych

C. Data analysis/statistics dane - analiza i statystyki D. Data interpretation interpretacja danych E. Preparation of manuscript przygotowanie artykułu F. Literature analysis/search wyszukiwanie i analiza literatury G. Funds collection zebranie funduszy
Tables: 6

Figures: 0

References: 24

Submitted: 2020 May 5

Accepted: 2020 Jul 24

\section{Summary}

Background. Regular physical activity allows maintenance of physical fitness at an optimal level and also contributes to greater care for other elements of a healthy lifestyle. The promotion of physical activity should be one of the tasks of health professionals, including physiotherapists. The aim of this study was to assess physical activity levels of physiotherapy students.

Material and methods. This study involved 853 students (634 women and 219 men) of the Faculty of Physiotherapy of the Medical University of Warsaw (444 first-year students and 409 second-year students). The research tools were the International Physical Activity Questionnaire - short version (IPAQ-SF) and the author's own survey to obtain information on the type of physical activity and reasons for taking it up or not.

Results. Men had significantly higher levels of physical activity than women $(p<0.001)$. The physical activity levels of second-year female students were higher than those of first-year female students $(\mathrm{p}=0.026)$. Among men, there was no significant difference between first and second-year students.

Conclusions. More than half of those surveyed do not engage in any physical activity outside of curriculum activities. The results obtained in this study may form the basis for continuing research with the participation of various groups of subjects and using more advanced technologies and research tools.

Keywords: physical activity, students, lifestyle, physiotherapy

\section{Streszczenie}

Wprowadzenie. Regularna aktywność fizyczna pozwala na utrzymanie wydolności fizycznej na optymalnym poziomie, a ponadto przyczynia się do większej dbałości o inne elementy zdrowego stylu życia. Propagowanie aktywności fizycznej powinno być jednym z zadań pracowników służby zdrowia, w tym fizjoterapeutów. Celem badania była ocena poziomu aktywności fizycznej studentów fizjoterapii.

Materiał i metody. W badaniu wzięło udział 853 studentów (634 kobiet i 219 mężczyzn) kierunku fizjoterapia Warszawskiego Uniwersytetu Medycznego (444 studentów pierwszego roku oraz 409 studentów drugiego roku). Narzędziami badawczymi były Międzynarodowy Kwestionariusz Aktywności Fizycznej - wersja krótka (IPAQ-SF) oraz autorska ankieta służąca uzyskaniu informacji dotyczącej rodzaju aktywności fizycznej oraz motywów jej podejmowania lub niepodejmowania.

Wyniki. Mężczyźni charakteryzowali się istotnie wyższym poziomem aktywności fizycznej niż kobiety $(\mathrm{p}<0,001)$. Poziom aktywności fizycznej studentek drugiego roku był wyższy niż $\mathrm{u}$ studentek pierwszego roku $(\mathrm{p}=0,026)$. Wśród mężczyzn nie stwierdzono istotnych różnic między studentami pierwszego i drugiego roku.

Wnioski. Ponad połowa badanych nie podejmuje żadnej aktywności fizycznej poza zajęciami programowymi. Uzyskane w niniejszej pracy wyniki mogą stanowić podstawę kontynuowania badań z udziałem różnych grup badanych oraz z wykorzystaniem bardziej zaawansowanych technologii i narzędzi badawczych.

Słowa kluczowe: aktywność fizyczna, studenci, styl życia, fizjoterapia 


\section{Introduction}

Lifestyle is one of the main factors determining the maintenance of health and psychophysical fitness [1]. Regular physical activity leads to morphological and functional changes in, among other things, the locomotive apparatus. An active lifestyle reduces the intensity of factors conducive to the development of civilization diseases, e.g. cardiovascular diseases or spinal pain syndromes [2-4]. Physical activity affects the human body. However, only systematically repeated motor tasks can affect health. This involves not only the improvement of physical fitness, but also the initiation of adaptive reactions [5,6].

It is assumed that physical activity has the greatest impact on the locomotive apparatus. Physical activity is a key factor in the maintenance of muscle fitness. Exercises with an appropriate level of resistance lead to an increase in muscle strength and mass. Owing to physical activity, muscles retain optimal length and flexibility and respond better to stimuli from the nervous system. An appropriate muscle work facilitates the arterial blood supply, which supplies muscles with oxygen and nutrients, and the outflow of venous blood, which removes metabolic products. The role of the muscle system in the maintenance of joint stability or the protection of the passive locomotive apparatus from overload and damage is also worth emphasizing [7].

Physical activity also affects cardiovascular function, both within the heart muscle and peripheral vessels. Movement reduces heart rate and resting blood pressure, as well as increases cardiac output, resulting in an improved heart muscle function and oxygen demand. Physical activity is therefore considered a key element in the prevention of cardiovascular disease [4].

A number of studies confirm that physical activity has a positive effect on other elements of a healthy lifestyle. This may have to do with both the environmental impact and the educational role of physiotherapists and instructors. The pedagogical aspect of the improvement process should be particularly highlighted. The awareness of the importance of lifestyle for the prevention of civilization diseases may result in or be the reasons for taking up physical activity [8-10]. Therefore, the promotion of physical activity should be one of the tasks of health professionals, including physiotherapists. The purpose of this study was to assess the level of physical activity of physiotherapy students. In addition, an attempt was made to determine the reasons for taking up physical activity or for refusing to do so, as well as preferences in terms of the discipline.

\section{Material and methods}

The study involved 853 students (634 women and 219 men) of the Faculty of Physiotherapy of the Medical University of Warsaw (444 first-year students and 409 second-year students) (Table 1). The survey was conducted between 2007 and 2015. Questionnaires (in paper form) were completed in the presence of the test taker. Participation in the study was voluntary and anonymous.

Table 1. Characteristics of examined people

\begin{tabular}{|c|c|c|c|c|c|c|}
\hline Year & \multirow{2}{*}{ Gender } & $\begin{array}{c}\text { Number } \\
\text { of people }\end{array}$ & $\begin{array}{c}\text { Age } \\
\text { [years] }\end{array}$ & $\begin{array}{c}\text { Body mass } \\
{[\mathbf{k g}]}\end{array}$ & $\begin{array}{c}\text { Body height } \\
{[\mathbf{c m}]}\end{array}$ & $\begin{array}{c}\text { BMI } \\
{\left[\mathbf{k g} / \mathbf{m}^{2}\right]}\end{array}$ \\
\hline I & \multirow{2}{*}{ women } & 328 & $19.43 \pm 0.9$ & $60.51 \pm 8.7$ & $168.19 \pm 6.2$ & $21.40 \pm 2.8$ \\
\cline { 3 - 8 } & & 306 & $20.56 \pm 1.1$ & $61.03 \pm 10.2$ & $168.50 \pm 6.5$ & $21.42 \pm 3.1$ \\
\hline II & \multirow{2}{*}{ men } & 116 & $19.47 \pm 1.4$ & $78.82 \pm 10.1$ & $181.12 \pm 5.9$ & $24.00 \pm 2.6$ \\
\cline { 1 - 7 } & & 103 & $20.69 \pm 1.6$ & $79.72 \pm 10.8$ & $181.80 \pm 6.4$ & $24.10 \pm 2.8$ \\
\hline
\end{tabular}

The study used the International Physical Activity Questionnaire-short version (IPAQ-SF) and the author's own survey. IPAQ-SF is a questionnaire that includes questions about physical activity performed in the last seven days. The questionnaire asked the respondents to indicate the time and frequency of intensive and moderate physical effort and the time spent in a sitting position. The level of physical activity is expressed in MET min/ week. The IPAQ-SF questionnaire also allows the participants to be classified into one of three categories of physical activity (high, moderate, low) [11]. The author's own survey included questions about the forms of physical activity undertaken, the reasons for taking it up or for refusing to do so (where the participants could indicate more than one answer), and biometric data.

The statistical tool used was arithmetic mean with standard deviation. Significant differences between the scores of each group were assessed using the Mann-Whitney $U$ test. The level of significance was defined at $\alpha=0.05$. Analyses were carried out using MS Excel and Statistica 10, under the license of the Medical University of Warsaw. 


\section{Results}

The physical activity levels of second-year female students were higher than those of first-year female students $(p=0.026)$. The largest differences were noted in relation to walking. Among men, there were no significant differences between first and second-year students (Table 2). Males showed significantly higher physical activity than females $(\mathrm{p}<0.001)$. The largest differences were found in the high intensity physical activity category.

Table 2. Level of physical activity

\begin{tabular}{|c|c|c|c|c|c|}
\hline \multirow{2}{*}{ Year } & \multirow{2}{*}{ Gender } & $\begin{array}{c}\text { Vigorous physical } \\
\text { activity [MET min/ } \\
\text { week] }\end{array}$ & $\begin{array}{c}\text { Moderate physical } \\
\text { activity [MET min/ } \\
\text { week] }\end{array}$ & $\begin{array}{c}\text { Walking [MET min/ } \\
\text { week] }\end{array}$ & $\begin{array}{c}\text { Sum [MET min/ } \\
\text { week] }\end{array}$ \\
\cline { 1 - 4 } I (n=328) & \multirow{2}{*}{ women } & $1221.2 \pm 1138.6$ & $702.2 \pm 671.3$ & $1634.4 \pm 1593.2^{*}$ & $3053.8 \pm 2570.5^{*}$ \\
\cline { 1 - 4 } & & $1286.8 \pm 1005.7$ & $820.4 \pm 735.3$ & $2004.6 \pm 1957.1^{*}$ & $3537.2 \pm 2853.6^{*}$ \\
\hline \multirow{2}{*}{ II (n=306) $(\mathrm{n}=116)$} & \multirow{2}{*}{ men } & $1974.8 \pm 1371.8$ & $837.9 \pm 781.1$ & $1683.6 \pm 1619.7$ & $3721.9 \pm 2518.7$ \\
\cline { 1 - 4 } II (n=103) & $2004.9 \pm 1624.4$ & $789.1 \pm 752.6$ & $1675.9 \pm 1200.1$ & $3989.4 \pm 2444.3$ \\
\hline
\end{tabular}

Notes: ${ }^{*} \alpha=0.05$ - differences between groups I and II

High levels of physical activity were reported by $36 \%$ of first-year female students and $47 \%$ of secondyear female students. Most of the women were classified in the moderate physical activity category. Men had the highest levels of physical activity: 52\% of first-year students and 59\% of second-year students rated their physical activity as high (Table 3).

Table 3. Categories of physical activity

\begin{tabular}{|c|c|c|c|c|}
\hline \multirow{2}{*}{ Year } & \multirow{2}{*}{ Gender } & $\begin{array}{c}\text { High level of physical } \\
\text { activity }\end{array}$ & $\begin{array}{c}\text { Moderate level of physical } \\
\text { activity }\end{array}$ & $\begin{array}{c}\text { Low level of physical } \\
\text { activity }\end{array}$ \\
\hline \multirow{2nnny}{*}{ I (n=328) } & \multirow{2}{*}{ women } & $118(36 \%)$ & $190(58 \%)$ & $21(6 \%)$ \\
\cline { 3 - 5 } II (n=306) & $143(47 \%)$ & $146(48 \%)$ & $17(6 \%)$ \\
\hline I (n=116) & \multirow{2}{*}{ men } & $60(52 \%)$ & $46(40 \%)$ & $10(9 \%)$ \\
\cline { 1 - 3 } II (n=103) & & $61(59 \%)$ & $32(31 \%)$ & $9(9 \%)$ \\
\hline
\end{tabular}

One in three students reported engaging in physical activity regularly at least twice a week. Slightly more participants were active among first year students (33\% first-year, 30\% second-year). The most common form of activity for women was running and fitness classes. Men preferred strength training and team games (Table 4).

Table 4. Types of physical activity

\begin{tabular}{|c|c|c|c|c|c|c|c|c|}
\hline Year & Gender & $\begin{array}{l}\text { Strength } \\
\text { training }\end{array}$ & Running & $\begin{array}{c}\text { Team } \\
\text { sports }\end{array}$ & Fitness & Dance & $\begin{array}{c}\text { Combat } \\
\text { sports }\end{array}$ & Swimming \\
\hline $\mathrm{I}(\mathrm{n}=103)$ & \multirow{2}{*}{ women } & $11(11 \%)$ & $22(21 \%)$ & $10(10 \%)$ & $22(21 \%)$ & $10(10 \%)$ & $4(4 \%)$ & $12(12 \%)$ \\
\hline II $(n=86)$ & & $12(13 \%)$ & $18(20 \%)$ & $5(6 \%)$ & $14(16 \%)$ & $14(16 \%)$ & $3(3 \%)$ & $4(5 \%)$ \\
\hline $\mathrm{I}(\mathrm{n}=43)$ & \multirow{2}{*}{ men } & $16(37 \%)$ & $3(7 \%)$ & $11(26 \%)$ & - & $1(2 \%)$ & $8(19 \%)$ & $3(7 \%)$ \\
\hline II $(n=39)$ & & $12(31 \%)$ & 7 (18\%) & $11(28 \%)$ & - & $1(2 \%)$ & 7 (18\%) & $2(5 \%)$ \\
\hline
\end{tabular}

Among the most frequently mentioned reasons for taking up physical activity were the maintenance of physical fitness, hobbies, energy discharge and release of psychophysical tension. Women were also more likely to report the desire for body mass reduction while men were more likely to aim for the development of the muscle tissue (Table 5). Lack of time and laziness were indicated as the main obstacles to physical activity (Table 6). 
Table 5. Reasons for taking up physical activity

\begin{tabular}{|c|c|c|c|c|c|c|c|}
\hline \multirow{2}{*}{ Year } & \multirow{2}{*}{ Gender } & $\begin{array}{c}\text { Physical } \\
\text { fitness }\end{array}$ & Hobby & $\begin{array}{c}\text { Mental well- } \\
\text { being }\end{array}$ & $\begin{array}{c}\text { Body mass } \\
\text { reduction }\end{array}$ & $\begin{array}{c}\text { Desire to } \\
\text { leave home }\end{array}$ & $\begin{array}{c}\text { Body } \\
\text { building }\end{array}$ \\
\cline { 1 - 6 } I (n=328) & \multirow{2}{*}{ women } & $277(84 \%)$ & $194(59 \%)$ & $191(58 \%)$ & $174(53 \%)$ & $121(37 \%)$ & $65(20 \%)$ \\
\cline { 1 - 6 } II (n=306) & $243(79 \%)$ & $150(49 \%)$ & $184(60 \%)$ & $188(61 \%)$ & $136(44 \%)$ & $73(24 \%)$ \\
\cline { 1 - 6 } I (n=116) & \multirow{2}{*}{ men } & $85(73 \%)$ & $84(72 \%)$ & $56(48 \%)$ & $35(30 \%)$ & $38(33 \%)$ & $76(65 \%)$ \\
\cline { 1 - 6 } II (n=103) & $79(77 \%)$ & $62(60 \%)$ & $57(55 \%)$ & $40(39 \%)$ & $39(38 \%)$ & $67(65 \%)$ \\
\hline
\end{tabular}

Table 6. Reasons for inactivity

\begin{tabular}{|c|c|c|c|c|c|}
\hline Year & Gender & Lack of time & Laziness & Health problems & Lack of money \\
\hline \multirow{2}{*}{ I (n=328) } & \multirow{2}{*}{ women } & $266(81 \%)$ & $158(45 \%)$ & $60(18 \%)$ & $47(14 \%)$ \\
\cline { 1 - 4 } II (n=306) & & $249(81 \%)$ & $172(56 \%)$ & $55(18 \%)$ & $46(15 \%)$ \\
\hline \multirow{2}{*}{ I (n=116) } & \multirow{2}{*}{ men } & $75(65 \%)$ & $64(55 \%)$ & $16(14 \%)$ & $21(18 \%)$ \\
\cline { 1 - 5 } II (n=103) & & $76(74 \%)$ & $60(58 \%)$ & $20(19 \%)$ & $16(15 \%)$ \\
\hline
\end{tabular}

\section{Discussion}

Civilization diseases pose a challenge for those involved in preventing and treating those diseases. An appropriate, healthy lifestyle - i.e., above all, regular physical activity - is of particular importance [12-14].

In the light of recent studies, most Polish students are characterized by a sufficient level of physical activity (about 2000-3000 MET min/week) [5,15-18]. The results of physiotherapy students were similar or slightly higher $[18,19]$. A significantly higher level of activity was reported only in students of the Faculty of Physical Education [20,21]. The students surveyed in this study declared physical activity at the level of about $3200 \mathrm{MET}$ min/week - women and $3700 \mathrm{MET}$ min/week - men. A significantly higher level of activity related to walking as a mean of transportation is noticeable. This may be due to the specificity of studies at the Medical University of Warsaw. Classes take place in different parts of the city and students, especially in their early years at the university, often move between different locations.

About 33\% of the students surveyed (as part of this study) declared regular physical activity at least twice a week for most of the academic year. This is a lower percentage than most researchers suggest. However, comparing these data with those of other authors is difficult due to differences in methodology. Some authors determined the activity of participants using a single question [16].

The choice of discipline was similar among students of different universities and majors. The most commonly reported disciplines were running, fitness (women), strength training (men) and team games [20,22]. The reason for taking up the activity was most often a desire to improve physical fitness and to improve well-being. Lack of time and laziness are among the reasons for inactivity $[20,23]$.

Consolidation of positive lifestyle habits can have a significant impact on health and should therefore be one of the objectives of physical activity. It has been shown that people who used to engage in physical activity in the past (whether for exercise or recreation) are more physically active at a later age and less likely to engage in risky health behaviors, such as smoking cigarettes [24]. In addition, people who engage in regular, organized physical activity often have higher levels of healthy behaviors $[8,12,13]$.

The drawback of the research was its subjectivity. However, a publicly available and widely reported questionnaire (IPAQ) was used. The solution could be to use additionally mobile applications that measure the overall level of activity related to the locomotion - pedometers. Research into lifestyle and physical activity certainly should be continued. Information on current trends in healthy behaviors will allow for the implementation of actions which activate students. Based on the information obtained, it seems justified to consider the modification of curricula at medical universities in order to draw more attention to the issues of prevention of civilization diseases.

\section{Conclusions}

1. Men reported higher physical activity than women both in the high and moderate intensity categories. A higher proportion of men showed also high levels of physical activity.

2. More than half of the physiotherapy students surveyed do not take up any physical activity outside of curriculum activities. This is mostly because of lack of time and laziness.

3. The results obtained in this study may form the basis for continuing research with the participation of various groups of subjects and using more advanced technologies and research tools. 


\section{References:}

1. Ostrowska A. [Lifestyle and health: assessment of the decade]. In: Domański H, Ostrowska A, Rychard A., editors. [How do Poles live?]. Warszawa: IFiS PAN; 2000. p. 101-120 (in Polish).

2. Dempsey PC, Strain T, Khaw KT, Wareham NJ, Brage S, Wijndaele K. Prospective associations of accelerometermeasured physical activity and sedentary time with incident cardiovascular disease, cancer, and all-cause mortality. Circulation. 2020; 141(13): 1113-1115. https://doi.org/10.1161/CIRCULATIONAHA.119.043030

3. Maddison R, Jiang Y, Foley L, Scragg R, Direito A, Olds T. The association between the activity profile and cardiovascular risk. Journal of Science and Medicine in Sport. 2016; 19(8): 605-610.

https://doi.org/10.1016/j.jsams.2015.08.001

4. Ślusarska B, Nowicki G. Health behaviours in prophylaxis of cardiovascular diseases among occupationally active population. Problemy Higieny i Epidemiologii. 2010; 91(1): 34-40.

5. Jakubowska L, Grabowska B, Seń M. Physical activity, health condition and lifestyle of academic youth. Journal of Education Culture and Society. 2019; 10(2): 201-215. https://doi.org/10.15503/jecs20192.201.215

6. Rozpara M, Nowak E, Nawrocka A, Polechoński J, Dębska M, Mynarski W. Evaluation of health benefits of peripheral resistance training based on energy expenditure in women aged 25-35 years. Health Prob Civil. 2019; 13(1): 30-37. https://doi.org/10.5114/hpc.2019.81107

7. Żebrowska A. [Physiological basis of physical training]. In: Kucio C, Nowak Z., editors. [Physical training in treating chosen diseases of internal organs. Why? How?]. Katowice: AWF Katowice; 2011. p. 7-42 (in Polish).

8. Boguszewski D, Adamczyk JG, Suchcicka B, Słyk E, Białoszewski D. The estimation of health-related behaviors of men practicing aikido and capoeira. Ido Movement for Culture. Journal of Martial Arts Anthropology. 2014; 14(2): 41-46.

9. Kubińska Z, Zaworski K, Mysula I, Pocztarska-Głos A. Physical activity in primary and secondary physioprophylaxis. Health Prob Civil. 2020; 14(1): 34-42. https://doi.org/10.5114/hpc.2020.92522

10. Yahia N, Wang D, Rapley M, Dey R. Assessment of weight status, dietary habits and beliefs, physical activity, and nutritional knowledge among university students. Perspectives in Public Health. 2016; 136(4): $231-244$. https://doi.org/10.1177/1757913915609945

11. Biernat E, Stupnicki R, Gajewski AK. International Physical Activity Questionnaire (IPAQ) - Polish version. Physical Education and Sport. 2007; 51(1): 47-54.

12. Boguszewski D, Adamczyk JG, Białoszewski D. Assessment of the health-related behaviors of men practicing combat sports and martial arts. Iranian Journal of Public Health. 2019; 48(10): 1794-1801. https://doi.org/10.18502/ijph.v48i10.3485

13. Bukova A, Zuskova K, Szerdiova L, Horbacz AD. Selected lifestyle factors of female university students as related to sports activities. Health Prob Civil. 2019; 13(1): 38-47. https://doi.org/10.5114/hpc.2019.81109

14. Grygiel-Górniak B, Tomczak A, Krulikowska N, Przysławski J, Seraszek-Jaros A, Kaczmarek E. Physical activity, nutritional status, and dietary habits of students of a medical university. Sport Sciences for Health. 2016; 12(2): 261-267. https://doi.org/10.1007/s11332-016-0285-x

15. Bergier B, Niźnikowska E, Stępień E, Szepeluk A, Bergier J. Physical activity of students, their leisure time and physical fitness self-assessment. Antropomotoryka. 2013; 64: 41-48. https://doi.org/10.5604/17310652.1111304

16. Sochocka L, Wojtyłko A. [Physical activity students of the medical and non-medical degree courses]. Environmental Medicine. 2013; 16(2): 53-58 (in Polish).

17. Baj-Korpak J, Korpak F, Szepeluk A, Sudoł G. [Factors conditioning the motives and obstacles to physical activity of students of physical education]. Rozprawy Społeczne. 2016; 10(4): 60-72 (in Polish).

18. Kotowski P, Ostrowska B. Assessment of physical activity among physiotherapy students. Rozprawy Naukowe AWF Wrocław. 2017; 56: 26-35.

19. Bergier B, Stepien E, Niznikowska E, Bergier J. Physical activity of male and female students of the State Higher Vocational School in Biała Podlaska, Poland. Medycyna Ogólna i Nauki o Zdrowiu. 2014; 20 (2): 51-57. https://doi.org/10.5604/20834543.1112232

20. Kościuczuk J, Krajewska-Kułak E, Okurowska-Zawada B. Physical activity of physiotherapy and dietetics students. Medycyna Ogólnai NaukioZdrowiu.2016;22(1):51-58.https://doi.org/10.5604/20834543.1198724

21. Guła-Kubiszewska H, Dębska U, Starościak W, Kałwa M, Hes B. Physical activity undertaken by physical education students in the context of declared health behaviors. Rocznik Lubuski. 2018; 44(2a): 242-258.

22. Madejski E, Bibro M, Wódka K, Łaczek-Wójtowicz M, Madejski R, Szalewski J. Leisure time physical activity of students of the institute of health sciences at the State Higher Vocational School in Tarnów. Health Promotion and Physical Activity. 2018; 4(5): 30-33. https://doi.org/10.5604/01.3001.0013.0819 
23. Gruchoła M. Physical activity of Poles in the light of public opinion polls. Health Prob Civil. 2018; 12(2): 99109. https://doi.org/10.5114/hpc.2018.74583

24. Woitas-Ślubowska D. Influence of participation in leisure time physical activity on tobacco and alcohol consumption among former athletes and non-athletes. Journal of Human Kinetics. 2009; 21: 119-126. https://doi.org/10.2478/v10078-09-0015-4 